Relations industrielles

Industrial Relations

\title{
Making Steel Under Free Trade ?
}

\section{Robert Storey}

Volume 48, numéro 4, 1993

URI : https://id.erudit.org/iderudit/050896ar

DOI : https://doi.org/10.7202/050896ar

Aller au sommaire du numéro

Éditeur(s)

Département des relations industrielles de l'Université Laval

ISSN

0034-379X (imprimé)

1703-8138 (numérique)

Découvrir la revue

Citer cet article

Storey, R. (1993). Making Steel Under Free Trade ? Relations industrielles /

Industrial Relations, 48(4), 712-731. https://doi.org/10.7202/050896ar

Tous droits réservés (C) Département des relations industrielles de l'Université Laval, 1993
Ce document est protégé par la loi sur le droit d'auteur. L'utilisation des services d'Érudit (y compris la reproduction) est assujettie à sa politique d'utilisation que vous pouvez consulter en ligne.

https://apropos.erudit.org/fr/usagers/politique-dutilisation/ 


\title{
Making Steel Under Free Trade?
}

\author{
Robert Storey
}

This paper examines the dynamics and the impact of the Free Trade Agreement (FTA) between Canada and the United States within the context of Canada's primary steel industry. It is argued that Canada's leading primary steelmakers supported the FTA because of their belief that steel markets were increasingly continental, and, because of their ideological adherence to the neoconservative agenda of corporate business and the federal Progressive Conservative government. Steelworkers and their union, the United Steelworkers of America, opposed the FTA because of the loss of jobs that would ensue with its implementation and because of its larger "right wing" economic and political direction. The paper concludes that while - to this point - it is difficult to differentiate the specific impact of the FTA from factors associated with industrial restructuring in the steel industry as a whole, the FTA is increasingly the central economic and political factor in the deepening crisis of the Canadian steel industry.

The national debate over free trade that occurred during the last years of the 1980s was based in a series of changes that seemed to be sweeping inexorably through Canada and the world as a whole. These changes, encapsulated in the term "new global economy," included most particularly the diffusion of information technologies, the internationalization of the division of labour, and heightened competition in all forms of basic and manufactured commodities. Proponents of a free trade agreement between Canada and the United States argued that eliminating tariffs on goods passing back and forth across the border was the best means by which Canadian industry could meet the challenges associated with this brave new economic and political world. As the advocates of free trade warned, if Canadian companies did not adjust, adapt

\footnotetext{
* Storey, R., Labour Studies and Sociology, McMaster University, Hamilton, Ontario.

** I would like to thank Pamela Sugiman for her helpful comments on a draft version of this paper.
} 
and, most importantly, take the initiative to become organizationally lean and internationally competitive, entire industries would falter and crumble and thousands of jobs would be lost forever. In the lexicon of the debate, there would be "losers" in the shift to untrammelled trade. Failure to press ahead would, however, result in many more company shutdowns than would be the case if Canada enthusiastically embraced free trade.

Others were more sceptical of what was viewed as an updated form of market determinism. Within this camp, a host of writers warned of the dangers of putting all of a nation's economic eggs in one trade basket - especially that of the United States which enjoyed much greater economic - and, thus, bargaining - power than did Canada. In this context, opponents of the proposed Free Trade Agreement (FTA) stated emphatically that Canadian industry would not be able to fully access American markets for their manufactured products; and, as critically, untold numbers of Canadian workers labouring in American branch plants would watch their jobs head south as their employers consolidated production facilities in locations that offered cost advantages such as lower wages, less stringent occupational health and safety regulations, municipal infrastructure incentives, and the like. For these individuals and organizations, the road ahead was to negotiate a multiplicity of trade deals with Canada's major trading partners, and, as importantly, press the federal government to formulate and implement an industrial policy that focused on moving away from a dependency on trade in resources to one where indigenous industry was promoted and nurtured. ${ }^{1}$

The owners and managers of Canada's primary steel companies were staunch supporters of the proposed free trade deal. ${ }^{2}$ The industry was slowly emerging from the recession of the early 1980 s and company executives were worried about rising protectionist sentiment in the American Congress aimed at providing aid to the bruised and battered American steel industry. Given that the United States was their largest export market, their fears were genuine. A semblance of calm was restored when the strongly free trade Reagan administration satisfied Congressional rumblings by securing Voluntary Restraint Agreements (VRAs) with over twenty countries that limited the amount of steel those countries could export to the United States. While winning exemption from these agreements, Canadian steelmakers nevertheless remained concerned that sooner or later they would be forced into making a similar deal;

1 For an elaboration of many of these points, see the readings in Gold and Leyton-Brown (1988), and Drache and Cameron (1985). For labour and popular opposition groups' arguments against the proposed North American Free Trade Agreement, see Sinclair (1992).

2 Primary steel makers are those companies which produce raw steel and then roll it into various forms prior to selling to their customers who process it into a desired shape. This paper will be almost exclusively concerned with Canada's primary steel industry. 
hence, their support for a free trade agreement that would forever exclude Canadian steel exports from similar restrictive arrangements.

Four years into the Free Trade Agreement (FTA) with the United States, and with the North American Free Trade Agreement (NAFTA) actively being negotiated, what are the circumstances of Canada's primary steel companies? First, like steel companies around the world, they are in the midst of a structural crisis a central component of which is the continuing build-up of world-wide productive capacity in the face of declining international and domestic demand. Second, this problem of excess capacity is compounded by the ongoing difficulties Canadian steelmakers are having in achieving unobstructed access to American markets. In short, the projected convoy of steel-laden trucks heading south across the border has not materialized. In fact, the opposite has occurred: American steel exports to Canada are on the rise.

Given these decidedly unfavourable developments, two questions need to be answered. One, how are we to explain the initial and now continuing support of Canadian steel executives for the FTA? As we shall see, the answer has two components: first, their belief that a free trade agreement that delivered on its promise of open access to American markets was, and remains, crucial to the overall viability of major sectors of the Canadian steel industry; and, second, their ideological adherence to the larger neo-conservative economic agenda - the need to get "lean and mean" in order to compete in the new global economy - which is utilized as a major weapon in their campaign to dampen militancy and opposition both within their workforces and the union that represents them.

The remaining question involves the responses of steelworkers and their union, the United Steelworkers of America (USWA). From the outset officials in the USWA predicted what has transpired: a free trade deal with the United States would fail in its stated objective of obtaining open access to American markets while simultaneously paving the way for an influx of American-made steel into Canada. The end result of both processes, the USWA warned, would be the elimination of thousands of jobs in the steel industry. The question that requires an answer is then: What are the strategic options open to the USWA in an era where free trade increasingly translates into a steady stream of layoffs and heightened employment insecurity for workers in primary steel?

\section{RESTRUCTURING IN THE UNITED STATES AND CANADIAN STEEL INDUSTRIES}

By world standards, the Canadian steel industry in the 1950s was small, with most of its production dedicated to satisfying the needs of the domestic market. Steel imports were double that of exports. The increasing appetite of 
Canadians for steel and intervention by the government, however, altered this situation in rather dramatic ways through the 1950s and 1960s. New tax policies were established that allowed steel companies to write off major investments in plant and technology in two years. Each of the country's four major integrated firms - the Steel Company of Canada (Stelco), Dominion Foundries and Steel (Dofasco), both in Hamilton, Ontario, Algoma in Sault Ste. Marie, and Hawker-Siddley in Sydney, Nova Scotia ${ }^{3}$ - took full advantage of these incentives to add to productive capacity. Through the 1950s and 1960s they made steel behind tariffs walls and within the context a selfregulated division of domestic markets (Masi 1991). Under these latter arrangements, there would be no costly or ruinous competition between Canadian steelmakers and the rate of growth in total productive capacity could be controlled to match any increases in demand.

The combination of these policies with other favourable conditions such as cheap raw materials and low labour costs, set the Canadian industry on a firm and profitable course into the early 1970s. Indeed, at this time Stelco, the country's largest steel producer, had sufficient confidence in steel markets that plans to construct a one billion dollar state-of-the-art greenfield steelmaking facility on the shores of Lake Erie were moved from the drawing board to the work site. ${ }^{4}$

Yet, if the 1970s were years of unprecedented growth for the Canadian steel industry, the same could not be said for its counterpart in the United States. Seemingly without warning, imported steel from Japan, West Germany and countries such as Brazil, South Korea, Taiwan, and Nigeria, began to carve out a significant percentage of American steel markets. Competition also appeared in the form of domestic mini mills - small, primarily non-union

3 An "integrated" steel company is comprised of three major divisions: a "blast furnace" where iron ore is produced; a "steelmaking" division where molten iron ore is combined with other materials to produce molten steel; and, "rolling mills" where the hardened steel is rolled down to various shapes and sizes in preparation for delivery to customers. Stelco, Algoma, and Hawker-Siddley had been integrated steelmakers since their inception in the opening years of the twentieth century. Dofasco joined their ranks when it added a blast furnace in the early 1950s. Until that time this non-union firm made steel by melting scrap in electric furnaces.

4 Built in Nanticoke, Ontario, "Lake Erie Works" came on-stream in the early 1980s the very moment when the recession hit Canada. When it was being constructed, there was widespread speculation that Stelco had plans to eventually make all of its steel in this new facility, turning the Hamilton plant into a series of finishing mills. The recession changed any such plans as it became much cheaper to modernize the Hamilton plant than to build completely new mills at the Lake Erie Works. Presently, it is Lake Erie Works that is the most efficient and competitive of all of Stelco's holdings. In fact, Lake Erie Works is second only to the Nucor minimill in Crawfordsville, Indiana, in productivity in terms of the number of person hours - two versus one - it takes to roll a ton of hot rolled steel. For a glowing exposition of the Nucor mill, see Preston (1991). 
firms with under one thousand employees, that made steel by melting scrap in electric furnaces, thus bypassing the costly processes of making pig iron and coke in blast furnaces and coking ovens respectively (Barnett and Crandall 1986). Of the two rivals, the giant American steel companies were most concerned about steel imports from overseas: the steel made in the mini mills was of a lower quality and geared to specialized products with lower profit margins. It soon became apparent, however, that the old and antiquated firms like U.S. Steel could not compete with the modern, technologically sophisticated and efficient newcomers - a fact which pushed the already teetering industry into profound crisis.

The response of American steelmakers was swift: each of the major companies embarked on rationalizing campaigns that resulted in the downsizing and complete shutdown of scores of mills. ${ }^{5}$ At the same time steel management began an aggressive drive to restructure their workplaces through the introduction of new technologies, the reshaping of jobs, the forcing of wage and other concessions, and the establishment of new work rules. ${ }^{6}$ By the early $1980 \mathrm{~s}$, the American steel industry was but a pale shadow of its former stature: the sprawling steelworks that dominated the urban landscapes of the northern United States, and which had symbolized its industrial might, stood quietly awaiting the wrecker's ball. Watching this transformation were over 250,000 steelworkers who had punched their time cards for the last time.

American steelmakers also initiated a campaign to exert pressure on their federal government to enact quotas on the import of raw and processed steel. By 1984, the ideologically free trade Reagan administration, mindful of the issue of jobs and the coming elections, yet reluctant to erect the legal barriers to trade contained in the Congress-initiated American Fair Trade In Steel Act, negotiated a series of VRAs with steelmakers around the world under which the percentage of imports to total consumption was to fall from a high of 26 percent to 18.5 percent. Put in place until 1989 , only Canada remained exempt from these restraint agreements. Indeed, the threatened passage of the far more restrictive American Fair Trade in Steel Act had served to galvanize Canadian steelmakers into an unprecedented show of unity. Under the umbrella of the newly-established Canadian Steel Producers Association (CSPA), company executives hurried back and forth to Washington as part of an extensive campaign designed to persuade American legislators that they were "fair" traders. Without question, it was the fear of seeing a billion-dollar-a-year market in danger of being undermined that informed Stelco president, John Allan's,

5 For example, see Barnett and Schorsch (1983), Hoerr (1988) and Reutter (1989).

6 For one of the most recent accountings of these changes, see Bain (1992). Other treatments of these problems and issues in England and Europe can be found in Houseman (1991), Meny and Wright (1987), and Hudson and Sadler (1989). 
personal plea before the Congressional committee in charge of formulating a legislative remedy to the influx of steel imports.

\begin{abstract}
Allan's testimony ...was a hymn to the integration of the Canadian and U.S. steel industries, which set Canada apart from the other nations whose steel exports were at stake and cried out for special treatment. Its keynotes were that the two industries were based on private enterprise, not government subsidy. They shared the same problem of a rising tide of unfairly traded steel from the creaking mills of Europe and state-of-the-art plants in South America and the Far East... They shared the same labor union, the same customer base, the same sources of iron ore, metallurgical coal and other raw resources... Not only were Canada and the United States each other's largest trading partner, ...they were also each other's largest export market for steel. (Partridge 1985: 26.)
\end{abstract}

In the end, these efforts proved successful but the privileged status of Canadian steelmakers was contingent on reducing their percentage of total steel imports into the United States from a high of five percent in 1984 down to the more traditional three percent.

This favourable conclusion failed to completely calm the anxiety of Canadian steel management. In fact, a major impetus behind the vigorous lobby for a reprieve from American import restrictions lay in the devastating impact of the 1981-82 recession on domestic markets. In 1980, Canadian steel mills produced 17.5 million tons of steel - a figure representing a capacity utilization of 84 percent. In 1981, production fell to 16.2 million tons, which because of additional capacity coming on stream, now represented 73.7 percent of total capacity. Still, this decline was only a harbinger of things to come. In 1982, Canadian steel mills produced only 13 million tons of steel, representing a capacity utilization of 55.2 percent. At the centre of this precipitous dropoff in production was decreased domestic demand for steel and steel products. In 1982, shipments of unprocessed steel within Canada amounted to approximately 13.2 million tons. One year later that figure stood at 10.3 million tons. As importantly, the apparent consumption (i.e. net domestic shipments including imports minus exports) of steel by Canadian consumers fell from 12.2 to 8.1 million tons over the same two year period. ${ }^{7}$

The following years, however, witnessed a remarkable recovery. The return of the automobile market bolstered Dofasco's profit picture, while favourable interest rates, a dollar whose value made Canadian products attractive to foreign customers, and an American steel industry still in the throes of restructuring, all combined to jump-start the remainder of the industry. By 1986, each of Stelco, Algoma and Sysco had returned to the black - a scenario

7 These statistics are taken from Locker Associates (1991). This is a document prepared for the May, 1991 Canadian Steel Technology and Employment Congress conference. 
which emboldened each firm to embark on expensive modernization plans. In 1984 , Dofasco announced plans to spend upwards of $\$ 600$ million dollars on the installation of continuous casting facilities and a new sheet mill. Algoma laid out its plans for a new seamless tube mill and other additions costing more than $\$ 400$ million. Sysco followed suit with an outlay of $\$ 100$ million dollars in the hope of revitalizing a desperately ailing steel works. And Stelco, burdened with a mammoth debt load resulting from the building of their Lake Erie plant and the loss of significant portions of their market, initiated the process of revamping their Hamilton plant at a cost of over $\$ 500$ million dollars (Chandler 1985; Heneault 1989).

These additions were not designed to add to productive capacity. Rather, the intent was on gaining a new competitive edge through qualitative changes in technology and work processes. One means of achieving this end was to use the new machinery to replace labour. In some instances this process was direct: the linking up of formally distinct processes via the installation of computer terminals eliminated the jobs of scores of workers. Another method - indirectly facilitated by the newer computer-based technologies - was the amalgamation of three and four jobs into one. On both counts the overriding purpose of the companies was evident: to rid themselves of "excess labour" and acquire greater "flexibility" through the creation of the all purpose production and maintenance worker (Petersen and Storey 1987; Sanger 1988). By the end of the 1980s, the "success" of these processes was palatable in that Canada's primary steel producers were capable of turning out approximately the same tonnage of steel as they had in the halcyon days a decade earlier. Now, however, they could do so with workforces reduced by thousands. ${ }^{8}$

This recovery notwithstanding, the recession left an indelible imprint on the Canadian steel industry. With substitute products coming on the market even as worldwide productive capacity continued to rise, it was increasingly evident that the cyclical problems of the early 1980 s were being transformed into a structural crisis of far-reaching proportions. One aspect of this emerging conundrum was the dramatic increase of steel imports into Canada. According to Locker, "imports as a percent of Apparent Consumption rose from 16\% to 28\%" between 1982 and 1990 (Locker Associates 1991: 25). As importantly from the standpoint of Canadian steelmakers, steel from the United States accounted for 56 percent of all imports by end of the 1980 s - up from 42 percent ten years earlier. Hence, as the shake-out was proceeding it appeared to Canadian steelmakers that their markets were now North American rather than

8 For various estimates on job loss in the basic steel industry during the 1980s, see Petersen and Storey (1987), Masi (1991), Blyton, et. al. (1989), Verma and Warrian (1992). In his book, Bain (1992) argues that job losses in the Canadian steel industry were less than seven other industrial countries, including the United States, Great Britain, West Germany and Japan. 
primarily domestic. This was confirmed by steel shipments going south of the border which by the late 1980 s had climbed to over 80 percent of all exports. This called for, as we have seen, an intensive effort on the part of Canadian steel management aimed at defending, and, if possible, expanding their customer base in the United States. Consequently, when the issue of free trade was put on the economic and political agenda through the influence of the Business Council on National Issues, and, in an historic reversal of position, the Canadian Manufacturers Association, there was little question that Canada's steelmakers would see such a development as being directly aligned with their long-term interest. ${ }^{9}$

\section{STEEL AND THE POLITICS OF FREE TRADE}

The rationale for the steel industry's backing of the free trade initiative, thus, lay mainly in the economic benefits which owners and top-level managers believed would accrue to their companies. These same individuals could not assume, however, that their enthusiasm was shared by their workforces or the USWA. It remained for them to convince both that free trade was the route to follow.

The efforts at persuasion were directed at workers' fears for their jobs - over 12,000 of which had disappeared by the mid 1980s. According to Stelco president, John Allan, each of the modernization and rationalization programs outlined above were situated in the context of steel companies being forced to "work the cost side of the margins" as they had "all but lost the luxury of working the price side." (Globe \& Mail, June 21, 1985: B1). This meant, first, that any demands for higher wages and other standard benefits would serve only to drive costs up and further endanger an already precarious process of recovery. In each set of contract negotiations during this period, management at Sysco, Stelco and Algoma drew dark pictures of possible and probable mill shutdowns should labour costs continue to soar beyond advances made in the United States and in other steel-producing nations. Indeed, it was in the context of threatened massive layoffs that workers at Algoma, while successfully fighting off company demands for wage and benefits concessions amounting to $\$ 2.41$ an hour from each employee, reluctantly agreed to a one year wage freeze in $1987 .{ }^{10}$

9 For interesting accounts of the impact of business interests on the evolution of free trade in Canada, see McQuaig (1991) and Doern and Tomlin (1991).

10 For an outline of the main points of the agreements reached between locals of the USWA and each of the primary steel companies, see Verma and Warrian (1992). For a more detailed picture of the deliberations and agreements between Stelco and Local 1005 at Hilton Works in Hamilton, see Adams and Zeytinoglu (1987). 
Efforts at bringing the workers onside also included company requests for greater cooperation between workers and management. Taking a page out of Dofasco's book on management paternalism (Storey 1983), each of the unionized firms implemented, in varying degrees, one version or another of the many human resource management programs circulating throughout North America. At Stelco, for example, after decades of pursuing an industrial relations policy in which management rights took precedence in every aspect of workplace relations (Kilbourn 1960; Freeman 1982), senior company officials now emphasized the need for greater two-way communication. Workers found themselves being ushered into rooms to watch videos extolling the virtues of more harmonious relations between workers and supervision. One of these virtues was improved product quality - a necessity, company officials argued, if the company was to compete effectively in the new global marketplace. ${ }^{11}$ To this latter end, Stelco put its senior management through seminars on constantly improving work practices, while those on management's front-lines, the supervisors, were exposed to an Interactive Management Training Program designed to breakdown old and obstructive authoritarian modes of dealing with workers, while the little-used suggestion box was replaced by an incentive plan that rewarded workers for ideas that enhanced the product and the environment of the plant as a whole. ${ }^{12}$

In the end, however, the differences between these two approaches were little more than illusory: both relied on instilling fear in workers about the longterm viability of their jobs. Indeed, the folded fist inside the velvet glove was revealed in the last days leading up to the 1988 federal election. Along with scores of employers across the country, Stelco, under the pen of its chief executive officers, included a letter with employee pay envelopes linking the future of the Canadian steel industry with the FTA. The letter, signed by then president Fred Telmer, took the form of a series of questions and answers, the ultimate message of which could not have been made any clearer.

Question: Why is the Free Trade Agreement so important to Stelco? Answer: We have had a long-term position in the United States market that became threatened in 1984 when off-shore imports caused severe job losses at U.S. steel companies. The U.S. wants to protect its flank from these imports, a situation that would restrict Canadian access to customers south of the border. The Free Trade

11 This latter point is made in a different context by Masi (1991) when he states that Canada's share of the U.S. market is not likely to increase in absolute terms. Hence, any inroads that can be made will have to be in the area of exporting higher quality, higher value-added steels.

12 For a more detailed discussion of these initiatives, see Livingstone (1992). In a 1990 speech, Bob Milbourne, then Works Manager of Stelco's Hilton Works, acknowledged that his company's "five year investment in employee relations, training, and attitudinal change, based on a commitment to secure, stable employment for the people in our manufacturing facilities was inadequate." (Quoted in Verma and Warrian 1992: 114). 
Agreement will protect the position we currently have in the U.S. as well as that of our customers.

Question: What happens if the Free Trade Agreement is not ratified by the Canadian Government and the Americans decide to include us in their import quotas...? Answer: If we don't have that preferred trade relationship with the U.S. through the negotiated pact, and the VRAs, which expire on Sept. 30 of 1989, are extended another five years, there will be great pressure to include Canada in this quota system... A global Voluntary Restraint Agreement will mean Stelco must reduce steel shipments to the U.S.... And that of course has a direct impact on jobs (Telmer 1988). ${ }^{13}$

While it is difficult to determine the effect these particular arguments had in influencing the opinions and actions of steelworkers across the country, the reaction of the USWA was clear and unequivocal. In accord with the Canadian labour movement as a whole, the USWA feared for the jobs of its members should the FTA become a reality. Already bleeding profusely from the fall-off in membership as a result of the recession, local and national USWA officials saw only further hemorrhaging if a deal was struck eliminating the 12 percent import duty on steel products. Indeed, in his November 1987 address to the House of Commons' Committee on International Trade, USWA National Director, Gerard Docquier, expressed his union's "deep concerns about the economic and the political consequences for Canada of free trade with the United States" (USWA 1987b: 1). ${ }^{14}$

Docquier's first difficulty lay in the area of domestic consumption of steel. This problem was critical, he related, as some 80 percent of the country's steel output was sold in Canada - making the "impact of free trade on steelusing industries in Canada ... far more significant for the industry than is its impact on direct exports of steel to the United States" (USWA 1987b: 3). With respect to domestic consumers, Docquier expressed his concern that the changes to the auto pact contained in the proposed FTA - especially in light of the instability of the industry as a whole - would have grim implications for the steel industry if rationalization favoured auto plants in the United States and if little or no duty remission accompanied future Japanese investment. Nor was the USWA optimistic about the impact of free trade on the steel industry's second largest customer: the oil and gas sector. Any arguments that Canada was going to benefit here, Docquier argued, were specious.

13 My thanks to USWA Local 1005 member, Bob Sutton, for searching his personal files for this material.

14 Docquier sat as a member of the Royal Commission on the Economic Union and Development Prospects for Canada, chaired by former Liberal cabinet minister, Donald Macdonald. He issued a dissenting report wherein he expressed many of the same concerns contained in the above document. 
The fact is that oil and gas development in Canada is not currently limited in any way by U.S. trade restrictions. Indeed, two minutes' thought on the issue would make it clear that it would be counter to U.S. interests to limit Canadian exports to the United States. The 'increased access' to the U.S. market guaranteed by the trade deal is irrelevant to the oil and gas industry and therefore to the steel industry (USWA 1987b: 7).

According to the USWA National Director, the situation was worse still in the final major areas of steel consumption - freight car manufacturing, white goods and small appliances. These industries would, Docquier related, "virtually disappear as surplus production capacity in the U.S. market spills over into Canada."

If free trade was to open Canadian markets to U.S. and other foreign imports, then the litmus test for the FTA lay in how well it would protect Canada's steel producers from American steel protectionism. Again, the USWA was not optimistic. In a document prepared for USWA members taking part in the free trade debate, the Union criticized the disputes resolution process of the FTA as a poor substitute for the stated objective of obtaining an exemption from American anti-dumping and countervailing duty laws. According to the USWA, the dispute resolutions review panel would have its hands tied by the "laws, precedents and practices of the country whose decision is being appealed." Critically,

Since the practices and precedents followed in the administration of U.S. trade law were what the fuss was all about in the first place, this really doesn't get us anywhere. If anything, we are worse off, because by participating in the review process, we are implicitly accepting the legitimacy of the U.S. trade laws that we have been complaining about for so long, and from which we originally sought an exemption (USWA 1988: 5).

This last point went to the centre of the USWA's concerns about the FTA. That is, if the disputes resolution process was destined to be ineffective, then the Canadian steel industry would be confronted, in the future as in the past, with anti-dumping and countervailing complaints by the U.S. steel industry - grievances which had more to do with the precarious nature of the U.S. steel industry and the politics of protectionism than they did with the question of who was a fair trader and who was not. ${ }^{15}$

15 Recent events bear out this concern of the USWA. Late January 1993 saw the U.S. International Trade Commission find a number of Canadian steel companies guilty of "dumping" (i.e. when goods are sold at prices that are lower than their selling price in their own domestic markets, or at prices that are less than their full cost) steel into the American market. Earlier in the same month Revenue Canada had imposed provisional duties on steel plate imports from nine countries, including 43 companies in the United States. This latter action was in response to pressure from Canadian steel companies and the USWA. 
Ultimately, the USWA, again like the Canadian labour movement as a whole, based its objections to the FTA in a larger economic and political context: fundamental opposition to the "right wing" agenda of the federal Conservatives. In an October 1987 speech on "Free Trade and the de-industrialization of Ontario," USWA District 6 Director, Leo Gerard, asked why a free trade deal "so obviously counter to Canada's interests" was carried forward by the Conservative government? His answer outlined the USWA's position that the "decision to go for a deal was not made with Canada's interests in mind. It was made in pursuit of broader goals which are dear to the hearts of the right wing in North America."

It wasn't hard for this Conservative government to give away our right to limit foreign investment. The government doesn't believe in restricting foreign investment anyway.

It wasn't hard for the Conservative government to give away our right to a madein-Canada energy policy. The government doesn't believe we should have an energy policy anyway.

Seen from the right wing perspective, such elements of the free trade agreement aren't concessions to the United States. They are an opportunity to enshrine in an international agreement domestic policies which, on their own, do not have the support of the majority of Canadians (USWA 1987a: 17).

\section{MAKING STEEL IN THE 1990s?}

Four years after its official implementation opinion polls reveal a deepseated mistrust of the FTA by a consistent majority of Canadians, while the right-wing agenda of the Conservative government is no longer shrouded in an ideological patina that espouses the sanctity of social programs even as the economic bases of those programs are systematically dismantled. There is no longer any doubt that the agenda of the ruling Conservatives is the agenda of the large and leading business interests. ${ }^{16}$ Moreover, there is no longer any doubt that the basic contours of Canadian economic and political life have been altered in ways that negate any attempt to return to business as usual.

Within this new and, as yet, highly unstable dynamic, stands a steel industry mired in crisis and deep discontent. On the one hand, even as the modern technologies purchased in the 1980s begin to earn some return on their investment, a refurbished and highly competitive United States industry, especially in the mini-mill sector, has eaten away at the cost advantage enjoyed by

16 See McQuaig (1991) for an analysis that holds to this view. See also, Clarkson (1991), and Richardson (1992). 
Canadian firms throughout the previous decade. ${ }^{17}$ As a consequence, the influx of steel imports into Canada from the United States - a source of concern by industry officials in their arguments for free trade - continues unabated: from 1988 to the fall of 1991 "U.S. penetration into the Canadian market has increased from $2 \%$ to $18 \%$. [In addition] imports comprise $28 \%$ of the total Canadian steel market and 50\% of the structural steel and rail markets" (Cook 1991: 19). On the other hand, Canadian steel exports south have dipped below their historical levels.

For different reasons both the steelmakers and the USWA see these two trends as worrisome. For their part, steel management, while judiciously maintaining their ideological commitment to free trade, now openly complain about the treatment their industry is receiving under the FTA. Their grievances are straightforward: while the lowering of tariffs has opened up the Canadian market to steel from the United States, the reverse has not been as true. According to Stelco's director for government relations, Don Belch, "Canadian steelmakers have at times been harassed with charges of illegally exporting products at prices below the domestic price..." (Toronto Star 1991: C1). In addition, American government officials, at the insistence of their steel industry, have "slapp[ed] Canadian steel with countervail duties to counteract the advantage of government subsidization." Such measures were mistaken, Belch continued, first, because they created the impression that all steel companies in Canada benefited from government assistance, whereas, in fact, only Sysco was buttressed by government funding; and, second, because " [s]tudies show the American steel industry received more than $\$ 30$ billion in various forms of government assistance during the 1980s..."

Industry solutions to these difficulties do not extend to abrogating the FTA. Rather, through the CSPA and the Canadian Steel and Employment Congress (CSTEC), a joint body of management and union representatives formed in 1985 to effect a "shared vision of trade and employment issues," industry spokesmen place the blame for their precarious economic fortunes squarely at the doorstep of high interest rates, the inflated value of the Canadian dollar and unfair trading practices by the United States. It was no doubt this latter concern that prompted CSTEC's executive board to present a resolution to the 1991 conference delegates calling for negotiations with the United States government to achieve "equal treatment for each of the parties

17 According to the Locker report, hourly labour costs per ton of cold-roll coil steel in Canada rose 86 percent from 1980 to 1990 , while wage increases among American steelworkers were negligible. In comparative terms, this meant that while Canadian hourly wages were $\$ 3.30$ lower than their southern counterparts in 1980, by 1989-90 Canadian hourly wages were 20 cents above those in the United States. However, when all benefits were included, Canadian steelworkers were at a $\$ 2.00$ an hour disadvantage. This is, however, a change from a $\$ 6.00$ disadvantage in 1980 (Locker 1991: 25). 
under the trade law, i.e., an equal playing field for both Canadian and US sellers." If such modifications could not be secured, the Canadian government was called upon to "announce its intention to adopt trade legislation which mirrors current US law" (CSTEC 1991).

For the USWA, discovering that their analyses of the impact of the FTA have proven essentially correct is little comfort to those workers who have lost their jobs either directly or indirectly as a consequence of its implementation. ${ }^{18}$ As importantly, it is equally disquieting to those workers who continue to labour in the blast furnaces and rolling mills amidst a second recession and a further shakeout of the industry that will diminish its formerly central place within a manufacturing sector that is itself undergoing rapid deterioration. That is, just as critics of the FTA suggested, the real importance of free trade lay not so much in the elimination of tariffs over a stipulated period of time. Rather, the fundamental significance of the FTA could be found in how it would affect investment decisions in - and out - of Canada. In terms of the embattled Canadian steel industry, evidence of such a change can be found in the machinations of the Regina-based mini-mill, Ipsco. After suffering through difficult times when the markets for its tubular products dwindled away in the early 1980s, Ipsco had recovered by the last quarter of the decade. At that moment, Ipsco's chief executive officer, Roger Philips, stood apart from most of his industry counterparts in opposing the FTA. Indeed, Philips served for two years as the chairman of the Council for National Unity. Presently, however, Ipsco is operating a new, non-union mill in Comanche, Iowa, where workers are earning "less than half the wage of the unionized Regina mill." As critically, with the United States accounting for a growing percentage of Ipsco's market, "the loyalty Philips feels to Regina - or Canada for that matter - doesn't reach much beyond the fact that most of his capital already is in the ground there. 'Our shareholders are shareholders, not patriots,' [Philips] stated drily...' I rather suspect that in five years, we will be making steel on both sides of the border." ' (Greenspon, April 1992: 56).

Concerns about the location of future investments are closely aligned with questions pertaining to the nature of those investments. That is, apart from a number of specific products associated with the automobile industry where Stelco and Dofasco have invested heavily, there is growing alarm that future developments will include greater rationalization of product lines and the

18 It is difficult to distinguish between those jobs lost to free trade and those lost due to recession and the crisis of overcapacity in the worldwide steel industry. As we will see below, however, it is probable that direct job loss is likely to become more of a problem over the next few years as steclmakers decide where to make investments. What is evident at this time, though, is the indirect job loss stemming from a decrease in demand of some 400,000 tons of steel because of the restructuring of Canada's manufacturing base. 
shutdown of processes that, in the face of shrinking domestic markets, no longer meet economies of scale. Hence, Stelco's reorganization plans at its main Hilton Works plant in Hamilton, could involve, according to its recently appointed president and chief operating officer, Bob Milbourne, selling off some of its cold rolling and steel coating processes (Cook 1991: 20). In concrete terms, the jettisoning of what these firms now believe to be peripheral parts of their finishing operations promises to narrow the product range of Canadian firms in such a manner as to not only force thousands more workers onto the unemployment rolls, but also to facilitate the process of continentalization whereby "Canadian steel companies will be called upon to supply Americans with semi finished products..." which would be processed into retail goods and possibly sold back to Canadian steel customers (Warrian 1984: 18).

As we move further into the post free trade era, it is this outcome which the USWA is attempting to mobilize against. Fearful that the many and various changes currently transforming the face of the Canadian basic steel industry will turn 1990s steelworkers into a further manifestation of hewers of wood and drawers of water, the Union has entered the debate on alternatives to free trade and protectionism. Most significantly at this point, the USWA played the leading role in the restructuring of the deeply-troubled Algoma Steel Company. Instead of the parent Dofasco's plans to mothball most of its finishing mills and reduce the workforce from 6,500 to between 2,000 and 3,000 workers in quick order, the "New Algoma"' will shed a smaller portion of its workforce gradually over five years, by which time the remaining employees will have a controlling interest in the firm by virtue of a stock ownership plan put in place in lieu of wage increases. According to the restructuring plan, worker/union representatives will sit on the executive board and joint committees will be established throughout the company to ensure worker participation and input at all levels of decision-making. ${ }^{19}$

19 How the "New Algoma" will actually function is, of course, difficult to say at this point. It is sufficient to point out that the experiment in what USWA National Director, Leo Gerard, has termed a new model of worker ownership influenced by West German structures of co-determination and Swedish example where management is less authoritarian, does have its critics in and out of the labour movement. For his part, right-wing business columnist, Terence Corcoran (1992) commented on the deal in the following manner: "... the union has to put a positive spin on this experiment in economic desperation - any collective agreement that calls for the greatest mass of union concessions in the history of the Canadian labour movement obviously needs to be dressed up a bit for public consumption - but spare us the the social-democracy co-determination propaganda. Admittedly, there isn't a lot you can do with a 15 per-cent wage cut, a cut in the work force of 2,600, major reductions in vacations, a freeze in production bonuses and a collective agreement that will remain in force for five years with only a chance of cost-ofliving increases if inflation makes a comeback. Fat chance." "Algoma is no paradigm for the 1990s," While in no way sharing in the polemic of these words, left and labour criticisms of the 
According to the USWA document, Empowering Workers in the Global Economy: A Labour Agenda for the 1990s, worker ownership, while not a panacea, is "an attractive strategy in part because worker-owned firms are likely to pursue business strategies with the high skill option"' (USWA 1992: 41). Pursuing the "high skill option" is a second critical plank in the USWA's 1990s labour agenda. Essentially, it points to practices such as exporting highly skilled, high waged jobs as fundamentally misguided business strategies if Canada is to have a manufacturing sector that contributes to "sustainable prosperity." This is true, the document states, because competing against newly-industrializing countries for low wage, low skill jobs is a no-win situation as Canadian workers would not, and should not, accept the wages and working conditions forced on their counterparts in Pacific Rim and Third World countries. And, relatedly, such a strategy does not generate a population with the spending power to fuel a market-based economy.

Aside from important questions being raised about the above USWA strategies as opening the doors to being co-opted by business and government interests via an acceptance of the ethos of competition, ${ }^{20}$ we are left with serious questions about the future viability of the Canadian steel industry. With all indicators pointing to a flat or even declining demand for steel over the next decade; and, with worldwide capacity still on the increase, the process of restructuring within the Canadian industry will continue with a vengeance. In practical terms, this means each of the major firms - and the increasingly important minor players like mini-mills of the Ipsco variety - will proceed quickly apace with strategies geared toward ever-lower "manning" levels and maximum labour process flexibility. At the same time, even as parts of production processes are either mothballed or sold off as a means to generate revenue for upgrading of other processes, additions that require large capital outlays will take the form of joint ventures with foreign investors. ${ }^{21}$ The inevitable result of each of the developments is the scaling down of the basic steel industry in Canada and the pervasive dilution of ownership of an industry that historically has been overwhelmingly Canadian.

How much the FTA is associated with these present and future trends is more easily discernible than what has transpired in the four years since its introduction. If, as this paper has noted, the significance of the FTA lays in the

\footnotetext{
Algoma agreement point to the same areas of concern, i.e., wage concessions, elimination of COLA, reduction in vacations, etc. In short, is the agreement really a pioneering move or a giant step in the direction of fundamental concessions?

20 For a labour critique of USWA policy, see Guindon (1992).

21 Both Stelco and Dofasco are involved with Japanese investors and steel companies the former in the financing and operation of its new galvanizing line, the latter in the construction and operation of a similar facility in Windsor, Ontario. Most recently, Dofasco has announced a joint venture with CO-STEEL build a \$200-300 million dollar minimill in the United States.
} 
overall economic and ideological framework it provides for large capital both Canadian and foreign, then it seems clear that continued free trade will ultimately refashion the Canadian steel industry into one that is continental in its production and market relations and global in its ownership patterns. Neither of these developments augers well for workers in the steel industry or the union that represents them.

\section{REFERENCES}

AdAms, R., and I. ZeYtinOGLu. 1987. "Labour-Management Dispute Resolution in Canadian Heavy Industry: The Hilton Works Case." Industrial Conflict Resolution in Market Economies. T. Hanami and R. Blanpain, eds. Antwerp: Kluwer Law and Taxation Publishers, 71-99.

BAIN, T. 1992. Banking the Furnace: Unions, Job Security, and Restructuring the Steel Industry in Eight Countries. Kalamazoo: W.E Upjohn Institute of Employment Research.

BARNETT, D., and L. SchoRSCH. 1983. Steel: Upheaval in a Basic Industry. Cambridge, Massachusetts: Ballinger Publishing Company.

BARnETt, D., and R. Crandall. 1986. Up from the Ashes: The Rise of the Steel Minimill in the United States. Washington: Brookings Institution.

Blyton, P., et. al. 1989. Human Resource Management in Canada and the United Kingdom Work Organizations: Strategies for Workforce Flexibility, Interim Report. London: Canadian High Commission.

Canadian SteEl and Employment Congress. 1991. Resolution of Canadian Steel and Employment Congress Executive. Ottawa, May.

Chandler, H. 1985. “A Profile of Canada's Steel Technology." Iron Age. April, 55-71.

Clarkson, S. 1991. "Disjunctions: Free Trade and the Paradox of Canadian Development." The New Era of Global Competition: State Policy and Market Power. D. Drache and M. Gertler, eds. Montreal: McGill-Queen's University Press, 103-126.

CoOK, J. 1991. "Recession Tests Steel Makers' Mettle." Canadian Machinery and Metalworking.

CorCoran, T. 1992. "Algoma is No Paradigm for the 1990s." Globe and Mail. April 18.

DOERn, B., and T. TOMLIN. 1991. Faith and Fear: The Free Trade Story. Toronto: Stoddart.

DraCHE, D., and D. CAMERON. 1985. The OTHER Macdonald Report. Toronto: Lorimer.

Freeman, B. 1982. 1005: Political Life in a Union Local. Toronto: Lorimer.

GolD, M., and D. LeYTon-Brown. 1988. Trade-Offs on Free Trade: The Canada-U.S. Free Trade Agreement. Toronto: Carswell.

Greenspon, E. 1992. "Nerves of Steel." Globe and Mail, Report on Business. Spring, 48-54. 
Guindon, S. 1992. "Putting the Con Back in the Economy." This Magazine. Vol. 25, No. 8, 17-22.

Heneault, R. 1989. The Competitive World - Is Canada Fit or a Mis-Fit? Kingston: Queen's University Industrial Relations Centre.

HOERR, J. 1988. And the Wolf Finally Came: The Decline of the American Steel Industry. Pittsburgh: University of Pittsburgh Press.

HoUSEMAN, S. 1991. Industrial Restructuring with Job Security: The Case of European Steel. Cambridge: Harvard University Press.

Hudson, R., and D. SAdLeR. 1989. The International Steel Industry: Restructuring, State Policies and Localities. London: Routledge.

KilboURN, W. 1960. The Elements Combined: A History of the Steel Company of Canada. Toronto: Clark Irwin and Company.

Livingstone, D. 1992. “Working at Stelco: 'Re-Tayloring' Production Relations in the Eighties." Recasting Steel Labour: The Stelco Story. J. Corman, M. Luxton, D. Livingstone and W. Seccombe, eds. Halifax: Fernwood, 13-53.

LOCKER Associates. 1991. The Canadian Steel Industry: Crisis and Prospects. New York: Locker Associates.

MASI, A. 1991. "Structural Adjustment and Technical Change in the Canadian Steel Industry, 1970-1986." The New Era of Global Competition: State Policy and Market Power. D. Drache and M. Gertler, eds. Montreal: McGill-Queen's University Press, 181-205.

MCQuAIG, L. 1991. The Quick and the Dead: Brian Mulroney, Big Business and the Seduction of Canada. Toronto: Viking.

MENY, Y., and V. WRIGHT. 1987. The Politics of Steel: Western Europe and the Steel Industry in the Crisis Years (1974-1984). New York: Walter de Gruyter.

PARTRIdGe, J. 1985. "Steel Makes a Stand." Globe and Mail, Report on Business Magazine. April, 22-27.

Petersen, J., and R. StOREY. 1987. Technological Change and Industrial Relations at Stelco's Hilton Works: Final Report. Ottawa: Labour Canada.

Preston, R. 1991. American Steel: Hot Metal Men and the Resurrection of the Rust Belt. New York: Prentice Hall.

ReUTTER, M. 1989. Sparrow's Point: Making Steel - The Rise and Ruin of American Industrial Might. New York: Summit Books.

Richardson, J. 1992. "Free Trade: Why Did it Happen?" Canadian Review of Sociology and Anthropolgy. Vol. 29, No. 3, 307-328.

SANGER, M. 1988. "Transforming the Elements: The Reorganization of Work and Learning at Stelco's Hilton Works." M.A. Thesis, University of Toronto.

SinClaIR, J. 1992. Crossing the Line: Canada and Free Trade with Mexico. Vancouver: New Star.

STOREY, R. 1983. "Unionization Versus Corporate Welfare: The Dofasco Way." Labour/Le Travailleur, vol. 12, 7-42.

Telmer, F. 1988. “'To Our Employees.” Hamilton: Stelco Steel. November 14.

TORONTO STAR. 1991. "Free Trade Failing Steel Firms, Official Says."' January 26. 
UNITED STEELWORKERS OF AMERICA (USWA). 1987a. "Leo Gerard: Free Trade and the De-Industrialization of Ontario." Toronto. October 21.

UNITED STEELWORKERS OF AMERICA (USWA). 1987b. "Gerard Docquier: Presentation on Free Trade to House of Commons Committee on International Trade." Toronto. November 30.

UNITED STEELWORKERS OF AMERICA (USWA). 1988. "Notes for Steelworker Participants in the Free Trade Debate." Toronto. February.

UNITED STEELWORKERS OF AMERICA (USWA). 1992. "Empowering Workers in the Global Economy." Toronto.

VERMA, A., and P. WARRIAN. 1992. "Structural Adjustment and Technical Change in the Canadian Steel Industry, 1970-1986." Industrial Relations in Canadian Industry. R. Chaykowski and A. Verma, eds. Toronto: Dryden, 87-135.

WARrian, P. 1984. "'Saving the Steel Industry: Beyond Free Trade vs Protectionism." Our Times, November, 15-18.

\section{L'industrie de l'acier et le libre-échange}

Le projet d'accord de libre échange (ALE) avec les États-Unis présenté par le gouvernement Mulroney a provoqué un débat national eu égard à ses avantages et inconvénients économiques et sociaux. L'ont supporté ces organisations et compagnies représentant le grand capital au Canada. Parmi elles, on retrouvait les propriétaires et dirigeants de compagnies d'acier primaire. Après avoir souffert de la dépression du début des années 1980 , le monde de l'acier était convaincu que sa reprise à court terme et, de façon plus importante, sa viabilité à long terme passaient par un plus grand accès aux marchés américains de l'acier. Donc, leur support pour l'ALE était basé sur leurs perceptions de leurs propres intérêts économiques. Il était également basé sur une adhésion idéologique à l'agenda économique et politique néo-conservateur présenté par les organisations d'affaires représentatives et par le Parti progressiste-conservateur fédéral. Alors que l'élection fédérale de 1988 approchait, les hauts dirigeants de la Steel Company of Canada (Stelco) à Hamilton, Ontario, ont envoyé une lettre à leurs employés les prévenant de la perte possible de marchés, et donc d'emplois, si l'accord de libre échange n'était pas implanté.

Les métallurgistes canadiens et leur syndicat, les Métallurgistes unis d'Amérique (MUA) s'opposèrent décidément à l'ALE. Dans sa campagne contre l'ALE, les MUA ont présenté en détail les problèmes et obstacles que les métallurgistes canadiens rencontreraient en accédant aux marchés américains et que le résultat serait à l'opposé des prétentions courantes, c'est-à-dire que les importations au Canada d'acier fabriqué aux États-Unis s'accroîtraient. Ils ont également prédit d'importantes pertes d'emploi dans l'industrie de l'acier, dans l'industrie manufacturière reliée à l'acier et dans les industries secondaires canadiennes, suite à la décision des américains de fermer leurs filiales 
canadiennes et de retourner chez eux où le climat était meilleur pour les investissements. Finalement, les MUA considérait l'ALE comme une application des politiques de l'aile droite du gouvernement progressiste conservateur fédéral, concentrées sur les intérêts comparatifs aux dépens des travailleurs.

Quatre ans après l'entrée en vigueur de l'ALE, l'industrie canadienne de l'acier primaire est dans un état de crise continue. Dans un contexte de surcapacité mondiale, au lieu de permettre un plus grand accès au marché américain, la circulation nord-sud de l'acier a été obstruée par les aciéries américaines et le gouvernement américain qui accusaient les producteurs d'acier canadien de faire du dumping et de diverses contraventions à l'ALE. Ces difficultés ont engendré colère et frustration chez les dirigeants d'aciéries canadiennes, eux qui se présentaient comme des échangistes honnêtes.

Les dirigeants locaux et nationaux des MUA place l'ALE au centre de leur analyse de la crise prévalant dans l'industrie canadienne de l'acier. En résumé, ils prétendent que leurs prédictions eu égard à l'accès aux marchés et la perte consécutive des manufacturiers secondaires ont agi ensemble pour produire de massives pertes d'emplois chez les métallurgistes et ainsi causer une préoccupation réelle quant à la viabilité de l'industrie canadienne dans sa forme actuelle. En réaction, les dirigeants nationaux et locaux des MUA et les dirigeants des compagnies d'acier se sont joints pour faire pression sur le gouvernement canadien ou bien pour forcer le gouvernement américain de respecter l'ALE ou bien pour établir des barrières légales similaires à celles érigés par les américains. En même temps, ils réclament un accord commercial sectoriel pour l'acier similaire à celui de l'automobile. Finalement, ils ont entrepris une campagne visant à convaincre les employeurs de l'importance de la qualification et du perfectionnement de la main-d'œuvre permettant alors de produire de l'acier à plus haute valeur ajoutée dans des marchés hautement compétitifs des années 1990 et au-delà.

Cet article conclut en affirmant qu'évaluer le nombre d'emplois perdus dans l'industrie de l'acier primaire dû à l'ALE est un exercice difficile, sinon impossible. Les technologies modernes et la machinerie implantée à la fin des années 1970 et durant les années 1980 ne visaient pas à accroître la capacité de production de l'acier. C'est plutôt aux changements technologiques et aux transformations organisationnelles qu'ils ont provoqués (v.g. l'élimination de divisions complètes, fusions d'emploi, la formation d'équipes, etc.) qu'il faut imputer la plus grande partie des emplois perdus pendant cette période. Cependant, comme le démontre la décision récente de deux compagnies de bâtir des usines aux États-Unis, le contexte politique et économique plus large et les changements reliés à la « nouvelle économie globale » qui affecte l'industrie canadienne de l'acier sont de plus en plus reliés à la réalité du libre échange. En résumé, le libre échange - avec les États-Unis et le Mexique - sera le contexte le plus important pour l'industrie canadienne de l'acier dans les années à venir. Si tel est le cas, alors non seulement plus d'emplois seront perdus, mais la viabilité même de l'industrie de l'acier primaire au Canada sera en jeu. 